CLINICAL STUDY

\title{
Identification of a deletion variant in the gene encoding the human $\alpha_{2 \mathrm{~A}}$-adrenergic receptor
}

\author{
A Hamann ${ }^{1}$, C Brieske $^{2}$, J Tafel ${ }^{1}$, P Buttron $^{2}$, B Schwarzloh ${ }^{2}$, H Münzberg $^{1}$, A Hinney ${ }^{3}$, H Mayer $^{4}$, W Siegfried ${ }^{5}$, \\ $\mathrm{J} \mathrm{Hebebrand}^{3}$, H Greten ${ }^{2}$, P Algenstaedt ${ }^{2}$ and R Ziegler ${ }^{1}$ \\ ${ }^{1}$ Abteilung Innere Medizin I, Medizinische Klinik und Poliklinik, Universität Heidelberg, Germany, ${ }^{2}$ Medizinische Kernklinik und Poliklinik, Universitäts- \\ Krankenhaus Eppendorf, Hamburg, Germany, ${ }^{3}$ Klinik für Psychiatrie und Psycho-therapie des Kindes- und Jugendalters, Philipps-Universität Marburg, \\ Germany, ${ }^{4}$ Klinik Hochried, Murnau, Germany and ${ }^{5}$ Adipositas-Rehabilitationszentrum Insula, Berchtesgaden, Germany
}

(Correspondence should be addressed to A Hamann, Abteilung Innere Medizin I, Medizinische Klinik und Poliklinik, Universität Heidelberg, Bergheimer Straße 58,69115 Heidelberg, Germany; Email: andreas_hamann@med.uni-heidelberg.de)

\begin{abstract}
Objective: The $\alpha_{2}$-adrenergic receptors are involved in the effects of catecholamines on energy metabolism. Of three known subtypes with differential expression, $\alpha_{2 \mathrm{~A}}$-adrenergic receptors are also localized in adipose tissue where they counteract the lipolytic activity of $\beta$-adrenergic receptors. This study was undertaken to assess whether variants in the $\alpha_{2 \mathrm{~A}}$-adrenergic receptor gene are associated with body weight.

Design and methods: Single strand conformation polymorphism (SSCP) screening and subsequent sequencing were applied to determine genetic variants in DNA samples from individuals with obesity, those of normal weight and those underweight.

Results: Analysis of the coding region resulted in the identification of an 18 bp deletion, with no other mutation found. Of 429 genotyped subjects, 7 carried the deletion, with no significant differences between lean and obese subjects. A previously identified polymorphism in the promoter of the $\alpha_{2 A^{-}}$ adrenergic receptor gene also did not show an association with any of the tested body weight categories.

Conclusion: Our data suggest that variants in the $\alpha_{2 \mathrm{~A}}$-adrenergic receptor gene are unlikely to contribute to the predisposition for the lean or obese state.
\end{abstract}

European Journal of Endocrinology 144 291-295

\section{Introduction}

Catecholamines play an important role in the regulation of metabolism in white and brown adipose tissue (1-3). Epinephrine and norepinephrine exert their action via adrenergic receptors, which belong to the family of seven transmembrane-segment receptors. In adipocytes, activation of $\beta_{1^{-}}, \beta_{2^{-}}$and $\beta_{3^{-}}$-adrenergic receptors by catecholamines leads to the stimulation of adenylate cyclase and generation of cAMP, mediated by the $G$ protein $G_{s}$. Conversely, sympathetic activation of the $\alpha_{2}$-adrenergic receptor leads to inhibition of adenylate cyclase and cAMP production via the $\mathrm{G}$ protein $G_{i}$. Intracellular cAMP levels in adipocytes control activity of protein kinase A which, in turn, regulates activation of hormone-sensitive lipase and thereby the lipolytic process. In brown adipocytes, initiation of lipolysis is a prerequisite for activation of thermogenesis (4).

In rodents, the $\beta_{3}$-adrenergic receptor is of major importance for lipolysis and thermogenesis, while the presence and functional importance of $\alpha_{2}$-adrenergic receptors in adipocytes are questionable (5). Furthermore, in murine fat cell lines, $\alpha_{2 \mathrm{~A}}$-adrenergic receptors have not been found (2). The human fat cell, on the other hand, contains predominantly $\beta_{1^{-}}$and $\beta_{2^{-}}$ adrenergic receptors responsible for the activation of lipolysis and $\alpha_{2 \mathrm{~A}}$-adrenergic receptors with the ability to counteract lipolytic activity (6). Three genes for the $\alpha_{2}$-adrenergic receptor located on different chromosomes have been identified, encoding for subtypes $\alpha_{2 \mathrm{~A}}$, $\alpha_{2 \mathrm{~B}}$ and $\alpha_{2 \mathrm{C}}$. As cellular distribution for the various subtypes is markedly different, only the $\alpha_{2 \mathrm{~A}}$-adrenergic receptor encoded on chromosome $10 \mathrm{q} 23-\mathrm{q} 25$ is responsible for the observed effects in adipose tissue (7).

Various pharmacological approaches using microdialysis and selective $\alpha_{2}$ - and $\beta$-adrenergic agonists and antagonists have been used to gain insight into the adrenergic control of fat cell function and nutritive blood flow in the surrounding tissue. Blockade of human $\alpha_{2}$-adrenergic receptors in vitro promotes enhancement of catecholamine-induced lipolysis (2, 8). Interestingly, heterogeneous distribution of $\alpha_{2^{-}}$ adrenergic receptors in various fat deposits seems to 
be involved in tissue and sex-specific differences of lipolytic activity $(9,10)$. Adipocytes from femoral subcutaneous fat deposits are less responsive to the lipolytic action of epinephrine than adipocytes from the omental or abdominal subcutaneous region. Furthermore, in gluteal fat depots of women low concentrations of epinephrine have a reduced lipolytic effect compared with fat of the same region obtained from men. This observation goes along with a higher number of $\alpha_{2}$-adrenergic receptors in female gluteal adipocytes, which could be responsible for the enhanced tendency of women to accumulate fat in this region.

Genetic factors play an important role in the regulation of energy metabolism and body weight. Products of relevant genes may be involved in the regulation of food intake, energy expenditure or nutrient partitioning (11). The sum of presumably several genetic effects and their interaction with environmental and behavioral conditions, such as increased caloric and fat intake or decreased physical activity, can result in energy imbalance and increased fat mass. In contrast, genetic factors could also predispose to leanness. Variants in the $\alpha_{2 \mathrm{~A}}$-adrenergic receptor could alter lipolytic activity in adipose tissue, making the $\alpha_{2 \mathrm{~A}}$-adrenergic receptor an attractive candidate gene for the dysregulation of energy balance. A mutation in the coding region of the $\alpha_{2 \mathrm{~A}}$-adrenergic receptor could deplete its antilipolytic action, resulting in reduced lipid storage and resistance to diet-induced obesity. Possibly, such a mutation in the $\alpha_{2 \mathrm{~A}}$-adrenergic receptor could also change its modulation of brown fat thermogenesis.

Besides their local effect in adipose tissue, $\alpha_{2^{-}}$ adrenergic receptors play an important role in the regulation of the sympathetic tone and could thereby influence energy balance (12). Therefore, a defect in the $\alpha_{2 \mathrm{~A}}$-adrenergic receptor protein could via various mechanisms predispose to a low body weight. On the other hand, a polymorphism in the promoter of the $\alpha_{2 \mathrm{~A}}$-adrenergic receptor gene could, depending on its effect on gene transcription, predispose to either underweight or obesity. Earlier studies had identified two restriction fragment length polymorphisms (RFLPs) in the $\alpha_{2 \mathrm{~A}}$-adrenergic receptor gene (DraI and Bsu36I) (13, 14). Controversial findings regarding the possible association of the DraI RFLP with hypertension have been reported $(15,16)$. In women, the DraI RFLP was shown to be associated with body fat distribution independent of body weight (17).

This study was undertaken to identify possible variants in the coding region of the $\alpha_{2 \mathrm{~A}}$-adrenergic receptor gene and to assess their association with different categories of body weight. In addition, we assessed the frequency of another previously identified polymorphism in the promoter of the $\alpha_{2 \mathrm{~A}}$-adrenergic receptor gene (18).

\section{Subjects and methods}

A cohort of extremely obese children and adolescents was recruited at the Children's Hospital Hochried and the Obesity Treatment Center Insula, which both specialize in the in-patient treatment of extremely obese young individuals. Ninety-seven percent of the obese subjects had a body mass index (BMI) above the 95th percentile, and 61\% exceeded the 100th BMI percentile, as determined in a large and representative epidemiological sample of the German population (19). For the purpose of this paper, we refrained from including information on age of onset of obesity because recall errors are most likely. The second study cohort of underweight students was recruited at the University of Marburg. They were characterized by the criteria of a BMI below the 13th percentile, absence of somatic disorders and consumption of less than 10 cigarettes per day. The present sample of underweight probands represents an extension of a study group described previously (20) and both cohorts have been characterized in detail elsewhere $(21,22)$. Mean \pm S.D. age in the obese and the lean study groups was $13.7 \pm$ 2.3 years and $25.4 \pm 4.0$ years respectively. The obese study group comprised $53 \%$ females, while $46 \%$ of the lean individuals were female. Two adult cohorts were recruited at the University of Hamburg, Germany: a group of adults with late onset obesity, BMI $38.5 \pm$ $5.0 \mathrm{~kg} / \mathrm{m}^{2}$, age $53.4 \pm 13.7$ years, and a control group of normal weight individuals with a BMI of $22.6 \pm$ $1.6 \mathrm{~kg} / \mathrm{m}^{2}$, age $50.2 \pm 18.4$ years.

The ethics committees of the participating universities approved all genetic studies. Written informed consent was obtained from all participants or, in the case of minors, their parents. According to the published sequence of the intronless $\alpha_{2 \mathrm{~A}}$-adrenergic receptor (23), the following primer pairs for the amplification of the $\alpha_{2 \mathrm{~A}}$-adrenergic receptor coding sequence were generated: pair 1, 5'-CCTTCATCTT CCGCCAGGAG- $3^{\prime}$ and 5'-GTAGCCCATGACCTCGTTGG$3^{\prime}$ (fragment size $348 \mathrm{bp}$, annealing temperature $\left(\mathrm{T}_{\mathrm{a}}\right)$ $61^{\circ} \mathrm{C}$ ); pair $2,5^{\prime}$-CGCTCGTCATCCCTTTCTCG-3' and $5^{\prime}-$ CCGCCGCCGCCCTTCTTCTC-3' $3^{\prime}\left(286 \mathrm{bp}, \mathrm{T}_{\mathrm{a}} 63^{\circ} \mathrm{C}\right)$; pair 3, 5'-TCCCGCCGCTCATCTCCATC- $3^{\prime}$ and 5'-CACGC GGGTGCGACGCTTGG-3' (191 bp, $\left.\mathrm{T}_{\mathrm{a}} 62^{\circ} \mathrm{C}\right)$; pair 4, 5'CTTCGCTCCCTGCCTCATCA-3' and 5'-GGTCCAGCGCG TCGGTGTCG- $3^{\prime}\left(263 \mathrm{bp}, \mathrm{T}_{\mathrm{a}} 63^{\circ} \mathrm{C}\right)$; pair 5, 5'-CGACACC GACGCGCTGGA- $3^{\prime}$ and $5^{\prime}$-GCGCTTCTCGAGGTTCTGC- $3^{\prime}$ $\left(256 \mathrm{bp}, \mathrm{T}_{\mathrm{a}} 64^{\circ} \mathrm{C}\right)$; pair $6,5^{\prime}$-CGACACCGACGCGCTG GAC-3' and 5'-GCCTGCAGTCAGCGTGAG-3' (538 bp, $\mathrm{T}_{\mathrm{a}} 59^{\circ} \mathrm{C}$ ). Seventy-five nanograms genomic DNA isolated from blood leukocytes were added to $20 \mu \mathrm{l}$ reaction mixture containing $0.4 \mu \mathrm{mol} / \mathrm{l}$ of each primer, $0.625 \mathrm{U}$ Taq DNA polymerase, $200 \mu \mathrm{mol} / \mathrm{l}$ of each dNTP and $2 \mu \mathrm{l} \mathrm{PCR}$ reaction buffer (Applied Biosystems, Weiterstadt, Germany) and $5-10 \%$ DMSO. Amplification was carried out in an automated thermal cycler (Biometra, Göttingen, Germany) over 35 cycles 
Table 1 Frequency of the deletion variant in the human $\alpha_{2 A}$-adrenergic receptor gene in different categories of body weight.

\begin{tabular}{|c|c|c|c|c|c|}
\hline & \multicolumn{2}{|c|}{ Allele frequency } & \multicolumn{3}{|c|}{ Genotype frequency } \\
\hline & Wildtype & $\overline{\text { Deletion }}$ & WT/WT $n(\%)$ & WT/D $n(\%)$ & $\mathrm{D} / \mathrm{D} n(\%)$ \\
\hline $\begin{array}{l}\text { Obese children and } \\
\text { adolescents }(n=195)\end{array}$ & 0.995 & 0.005 & $\begin{array}{l}193 \\
(99.0)\end{array}$ & $\begin{array}{l}2 \\
(1.0)\end{array}$ & $\begin{array}{c}0 \\
(0)\end{array}$ \\
\hline $\begin{array}{l}\text { Obese adults } \\
(n=48)\end{array}$ & 1.0 & 0.0 & $\begin{array}{c}48 \\
(100)\end{array}$ & $\begin{array}{l}0 \\
(0)\end{array}$ & $\begin{array}{l}0 \\
0 \\
(0)\end{array}$ \\
\hline $\begin{array}{l}\text { Normal weight subjects } \\
(n=58)\end{array}$ & 0.983 & 0.017 & $\begin{array}{l}56 \\
(96.5)\end{array}$ & $\begin{array}{l}2 \\
(3.5)\end{array}$ & $\begin{array}{l}0 \\
0 \\
(0)\end{array}$ \\
\hline $\begin{array}{l}\text { Underweight subjects } \\
(n=128)\end{array}$ & 0.988 & 0.012 & $\begin{array}{l}125 \\
(97.6)\end{array}$ & $\begin{array}{l}3 \\
(2.4)\end{array}$ & $\begin{array}{l}0 \\
(0)\end{array}$ \\
\hline
\end{tabular}

WT $=$ Wildtype, $\mathrm{D}=$ deletion

$\chi^{2}$-test: obese children/adolescents vs underweight subjects $P=0.350$; obese children/adolescents vs normal weight subjects $P=0.196$; obese adults vs underweight subjects $P=0.452$.

at $94^{\circ} \mathrm{C}$ for $1 \mathrm{~min}$, at the indicated annealing temperature for $1 \mathrm{~min}$ and at $72^{\circ} \mathrm{C}$ for $2 \mathrm{~min}$, with template-free controls included in each experiment.

For single strand conformational polymorphism (SSCP) analysis, aliquots of PCR products were separated on a Multiphor II Electrophoresis Unit using CleanGels 48S (Pharmacia Biotech, Freiburg, Germany) at $14^{\circ} \mathrm{C}$ and visualized by silver staining, all according to the manufacturer's instructions. Amplified fragments were cloned into the TA vector (Invitrogen, Groningen, The Netherlands) and isolation of plasmid DNA was performed with the JET Quick Plasmid Miniprep (Genomed, Bad Oeynhausen, Germany). Sequencing was carried out with the dRhodamine Terminator Ready Reaction Kit with Amplitaq DNA Polymerase FS on an ABI Prism 377 (Applied Biosystems).

Genotyping for the identified deletion was performed by agarose gel electrophoresis after amplification of genomic DNA with primer pair 4 (see above). Long and short alleles were identified after staining with ethidium bromide based on their different electrophoretic migration rates.

A 502 bp fragment of the $\alpha_{2 \mathrm{~A}}$-adrenergic receptor gene promoter was amplified using the primer pair $5^{\prime}$ TCACACCGGAGGTTCATTCCCTCG-3' and 5'-TCCGAC
GACAGCGCGAGTT-3' $\left(\mathrm{T}_{\mathrm{a}} 63^{\circ} \mathrm{C}\right)$. Genotyping for the $\mathrm{C} / \mathrm{G}$ polymorphism at position -1291 of the $\alpha_{2 A^{-}}$ adrenergic receptor gene promoter was performed by digestion with the restriction enzyme MspI, followed by agarose gel electrophoresis.

Differences in allele frequencies between cohorts of different body weight were evaluated by $\chi^{2}$-test.

\section{Results}

With each primer set, PCR yielded amplimers of the expected sizes. SSCP screening of the intronless coding region of the $\alpha_{2 \mathrm{~A}}$-adrenergic receptor gene using 6 different primer pairs and sequencing of PCR fragments with altered migration patterns resulted in the identification of an insertion/deletion polymorphism. Compared with the published wildtype sequence, 18 base pairs were deleted in a region of the gene corresponding to amino acids 255-260 of the $\alpha_{2 A}$-adrenergic receptor. No further variants were detected.

Allele and carrier frequencies of the deletion variant were determined by subsequent genotyping in cohorts of individuals with different body weights, as shown in Table 1. Of the 429 genotyped probands, 7 were heterozygous for the deletion: 2 of 195 obese children and adolescents, 3 of 125 underweight subjects and 2

Table 2 Frequency of the promoter polymorphism in the human $\alpha_{2 \mathrm{~A}}$-adrenergic receptor gene in different categories of body weight.

\begin{tabular}{|c|c|c|c|c|c|}
\hline & \multicolumn{2}{|c|}{ Allele frequency } & \multicolumn{3}{|c|}{ Genotype frequency } \\
\hline & $\mathrm{C}$ & $\mathrm{G}$ & $\mathrm{C} / \mathrm{C} n(\%)$ & $\mathrm{C} / \mathrm{G} n(\%)$ & $\mathrm{G} / \mathrm{G} n(\%)$ \\
\hline $\begin{array}{l}\text { Obese adults } \\
(n=107)\end{array}$ & 0.776 & 0.224 & $\begin{array}{l}65 \\
(60.7)\end{array}$ & $\begin{array}{l}36 \\
(33.7)\end{array}$ & $\begin{array}{l}6 \\
(5.6)\end{array}$ \\
\hline $\begin{array}{l}\text { Normal weight subjects } \\
(n=60)\end{array}$ & 0.750 & 0.250 & $\begin{array}{l}34 \\
(56.7)\end{array}$ & $\begin{array}{l}22 \\
(36.7)\end{array}$ & $\begin{array}{l}4 \\
(6.7)\end{array}$ \\
\hline $\begin{array}{l}\text { Underweight subjects } \\
(n=118)\end{array}$ & 0.771 & 0.229 & $\begin{array}{l}71 \\
(60.2)\end{array}$ & $\begin{array}{l}40 \\
(33.9)\end{array}$ & $\begin{array}{l}7 \\
(5.9)\end{array}$ \\
\hline
\end{tabular}

$\chi^{2}$-test: obese vs underweight subjects $P=0.909$ obese vs normal weight subjects $P=0.594$; normal weight vs underweight subjects $P=0.656$ 
of 56 normal weight subjects, with 0 of 48 obese adults. Nobody homozygous for the deletion was detected. No significant differences in allele frequencies between cohorts of different body weights were assessed by $\chi^{2}$-test. Combining both obese cohorts for statistical analysis versus subjects with normal weight or underweight resulted in a $P$ value of 0.123 .

Genotyping for the $\mathrm{C} / \mathrm{G}$ polymorphism at position -1291 of the $\alpha_{2 \mathrm{~A}}$-adrenergic receptor gene was carried out by RFLP analysis, since the polymorphism introduces an additional MspI site. This resulted in the predicted fragment sizes of $174,165,116,62$ and $5 \mathrm{bp}$ for the wildtype allele compared with $165,121,116$, 62, 53 and $5 \mathrm{bp}$ for the mutant allele. As shown in Table 2, RFLP analysis revealed no significant differences in allele or genotype frequencies between the study groups.

\section{Discussion}

Given its role in the regulation of lipolysis in adipose tissue and systemic control of sympathetic tone, defects in the $\alpha_{2 \mathrm{~A}}$-adrenergic receptor could predispose an individual to alterations in body weight. Since the $\alpha_{2 A^{-}}$ adrenergic receptor has the potency to counteract the effects of the various $\beta$-adrenergic receptors on lipolysis and thermogenesis, it is an attractive candidate gene for states of altered triglyceride storage, such as underweight. Our results, however, indicate that variability in the $\alpha_{2 \mathrm{~A}}$-adrenergic receptor gene is not involved in different body weight regulation in humans. In the entire coding sequence, only one variant was found and was shown to be very rare among all genotyped individuals. The prevalence of a more frequent polymorphism in the promoter region of the $\alpha_{2 \mathrm{~A}}$-adrenergic receptor gene was not significantly different between individuals of different weight categories.

The deletion variant is located in the third cytoplasmatic domain of the $\alpha_{2 \mathrm{~A}}$-adrenergic receptor, deleting amino acids 255-260 (Pro-Glu-Arg-Ser-Ala-Gly). It is not known whether this specific region is of critical relevance for the function of the $\alpha_{2 \mathrm{~A}}$-adrenergic receptor, e.g. G protein coupling.

Mice completely lacking functional $\alpha_{2 \mathrm{~A}}$-adrenergic receptors due to disruption of the gene in embryonic stem cells were reported to have an increased sympathetic activity (24). While this was associated with resting tachycardia, body weight was reported to be normal. However, this does not exclude the possibility that the $\alpha_{2 \mathrm{~A}}$-adrenergic receptor has a role to play in human body weight regulation. It is well documented that an increase in sympathetic tone can promote weight loss in humans, as observations with ephedrine and caffeine, other sympathomimetic compounds and sibutramine have shown $(25,26)$. Also, mild to moderate effects of yohimbine and other $\alpha_{2}$-adrenoceptor antagonists on body weight, lipid mobilization and other features of energy metabolism have been demonstrated in humans, dogs and other mammalian species (2). According to the concept of susceptibility genes, a relevant defect in the $\alpha_{2 \mathrm{~A}^{-}}$ adrenergic receptor gene would only be expected to represent one of presumably multiple genetic factors predisposing an individual towards the development of underweight or obesity. The development of the phenotype would generally depend on interactions between genes and environmental conditions, such as diet and exercise. In this context, genetic defects in the $\alpha_{2 \mathrm{~A}}$-adrenergic receptor could possibly prevent excess lipid storage when humans or animals are exposed to a high fat diet.

An MspI RFLP in the promoter region of the $\alpha_{2 \mathrm{~A}^{-}}$ adrenergic receptor gene was shown to result from a C/G substitution 1291 bp upstream from the transcription start site $(18,27,28)$. Previous association studies have focussed on human hypertension and psychiatric disorders, but did not detect statistically different prevalences between phenotypically different cohorts. No studies have been performed regarding the possible effect of this variant on $\alpha_{2 \mathrm{~A}}$-adrenergic receptor gene expression and receptor density. However, we did not detect any evidence that such a possible effect of the polymorphism could be associated with body weight regulation. Since all our study groups are of German origin, we cannot fully exclude the possibility that association may be found in other ethnic populations. In summary, our data make it rather unlikely that variants in the $\alpha_{2 \mathrm{~A}}$-adrenergic receptor gene contribute to interindividual differences in body weight.

\section{Acknowledgements}

This work was supported by the Deutsche Forschungsgemeinschaft (DFG) and by the European Community (Framework V 'Factors in healthy eating').

\section{References}

1 Lafontan M \& Berlan M. Fat cell adrenergic receptors and the control of white and brown fat cell function. Journal of Lipid Research 199334 1057-1091.

2 Lafontan M \& Berlan M. Fat cell alpha 2-adrenoceptors: the regulation of fat cell function and lipolysis. Endocrine Reviews $199516716-738$.

3 Arner P. Catecholamine-induced lipolysis in obesity. International Journal of Obesity and Related Metabolic Disorders 23 (Suppl. 1) 1999 10-13.

4 Lowell BB \& Spiegelman BM. Towards a molecular understanding of adaptive thermogenesis. Nature $2000 \mathbf{4 0 4} 652-660$.

5 Valet P \& Saulnier-Blache JS. Metabolic and trophic role of catecholamines in the development of white adipose tissue. Annales d'Endocrinologie $199960167-174$.

6 Lafontan M \& Berlan M. Evidence for the alpha 2 nature of the alpha-adrenergic receptor inhibiting lipolysis in human fat cells. European Journal of Pharmacology 198066 87-93.

7 Castan I, Devedjian JC, Valet P, Paris H \& Lafontan M. Human adipocytes express alpha 2-adrenergic receptor of the alpha $2 \mathrm{~A}$ subtype only: pharmacological and genetic evidence. Fundamental and Clinical Pharmacology 1995 9 569-575. 
8 Lafontan M, Barbe P, Galitzky J, Tavernier G, Langin D, Carpene C et al. Adrenergic regulation of adipocyte metabolism. Human Reproduction 12 (Suppl. 1) 1997 6-20.

9 Kather H, Zollig K, Simon B \& Schlierf G. Human fat cell adenylate cyclase: regional differences in adrenaline responsiveness. European Journal of Clinical Investigation 1977 7 595-597.

10 Wahrenberg H, Lonnqvist F \& Arner P. Mechanisms underlying regional differences in lipolysis in human adipose tissue. Journal of Clinical Investigation $1989 \mathbf{8 4} 458-467$.

11 Barsh GS, Farooqi IS \& O'Rahilly S. Genetics of body-weight regulation. Nature $2000 \mathbf{4 0 4} 644-651$.

12 Hein L, Altman JD \& Kobilka BK. Two functionally distinct alpha 2-adrenergic receptors regulate sympathetic neurotransmission. Nature $1999 \mathbf{4 0 2} 181-184$.

13 Hoehe MR, Berrettini WH \& Lentes KU. DraI identifies a two allele DNA polymorphism in the human alpha 2-adrenergic receptor gene (ADRAR), using a $5.5 \mathrm{~kb}$ probe (p ADRAR). Nucleic Acids Research $1988 \mathbf{1 6} 9070$.

14 Sun L, Schulte N, Pettinger P, Regan JW \& Pettinger WA. The frequency of alpha 2-adrenoceptor restriction fragment length polymorphisms in normotensive and hypertensive humans. Journal of Hypertension $1992101011-1015$.

15 Lockette W, Ghosh S, Farrow S, MacKenzie S, Baker S, Miles P et al. Alpha 2-adrenergic receptor gene polymorphism and hypertension in blacks. American Journal of Hypertension $1995 \mathbf{8}$ 390-394.

16 Michel MC, Plogmann C, Philipp T \& Brodde OE. Functional correlates of alpha(2A)-adrenoceptor gene polymorphism in the HANE study. Nephrology, Dialysis, Transplantation 199914 2657-2663.

17 Oppert JM, Tourville J, Chagnon M, Mauriege P, Dionne FT, Perusse L et al. DNA polymorphisms in the alpha 2- and beta 2adrenoceptor genes and regional fat distribution in humans: association and linkage studies. Obesity Research 19953249 255.

18 Lario S, Calls J, Cases A, Oriola J, Torras A \& Rivera F. MspI identifies a biallelic polymorphism in the promoter region of the alpha 2A-adrenergic receptor gene. Clinical Genetics $1997 \mathbf{5 1}$ 129-130.

19 Hebebrand J, Heseker H, Himmelmann GW, Schäfer H \& Remschmidt H. Percentiles for the body mass index based on data of the German National Nutrition Survey and a review of relevant factors with an influence on body weight. Aktuelle Ernährungsmedizin $199419259-265$.

20 Hinney A, Barth N, Ziegler A, von Prittwitz S, Hamann A, Hennighausen $\mathrm{K}$ et al. Serotonin transporter gene-linked polymorphic region: allele distributions in relationship to body weight and in anorexia nervosa. Life Sciences 199761 PL295303.

21 Hamann A, Tafel J, Büsing B, Münzberg H, Hinney A, Mayer H et al. Analysis of the uncoupling protein-1 (UCP1) gene in obese and lean subjects: identification of four amino acid variants. International Journal of Obesity and Related Metabolic Disorders 199822 939-941.

22 Hamann A, Münzberg H, Buttron P, Büsing B, Hinney A, Mayer H et al. Missense variants in the human peroxisome proliferatoractivated receptor-gamma 2 gene in lean and obese subjects. European Journal of Endocrinology 1999141 90-92.

23 Kobilka BK, Matsui H, Kobilka TS, Yang-Feng TL, Francke U, Caron MG et al. Cloning, sequencing, and expression of the gene coding for the human platelet alpha 2-adrenergic receptor. Science 1987238 650-656.

24 Altman JD, Trendelenburg AU, MacMillan L, Bernstein D, Limbird L, Starke K et al. Abnormal regulation of the sympathetic nervous system in alpha2A-adrenergic receptor knockout mice. Molecular Pharmacology 199956 154-161.

25 Astrup A. The sympathetic nervous system as a target for intervention in obesity. International Journal of Obesity and Related Metabolic Disorders 19 (Suppl. 7) 1995 S24-S28.

26 Stock MJ. Sibutramine: a review of the pharmacology of a novel anti-obesity agent. International Journal of Obesity and Related Metabolic Disorders 21 (Suppl. 1) 1997 S25-S29.

27 Ohara K, Nagai M, Tani K, Tsukamoto T \& Suzuki Y. Polymorphism in the promoter region of the alpha $2 \mathrm{~A}$ adrenergic receptor gene and mood disorders. Neuroreport 199891291 1294.

28 Ohara K, Suzuki Y, Ochiai M \& Terada H. Polymorphism in the promoter region of the alpha(2A)-adrenergic receptor gene and panic disorders. Psychiatry Research 200093 79-82.

Received 17 July 2000

Accepted 16 October 2000 